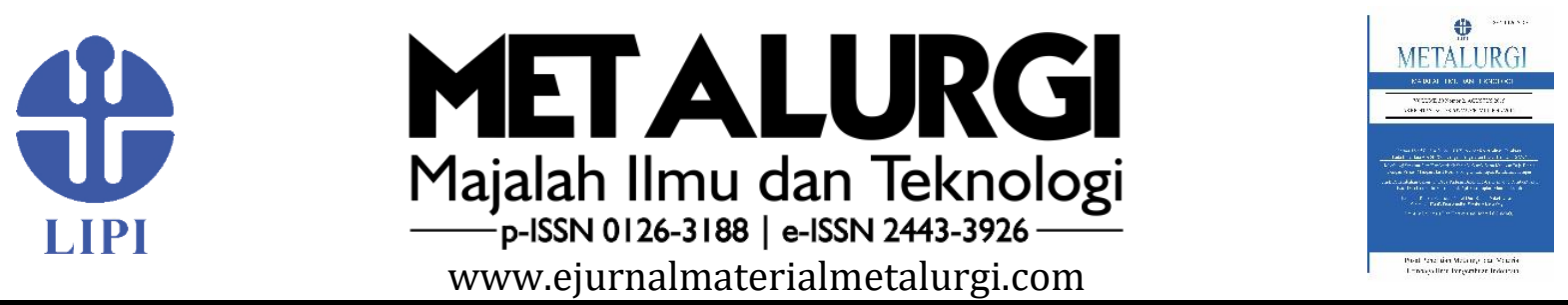

\section{The Product Characteristics of Treated Ferronickel Slag Produced by Alkali Fusion and Carbothermic Process}

\author{
Reza Miftahul Ulum ${ }^{a}$,*, Burhanuddin As-Siraja, Latifa Hanum Lalasarib, Wahyu \\ Mayangsari $^{\mathrm{b}}$

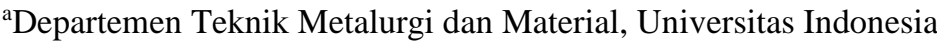 \\ Jl. Kampus UI Depok, Depok, Jawa Barat, Indonesia 16424 \\ ${ }^{\mathrm{b}}$ Pusat Penelitian Metalurgi dan Material \\ Gedung 470, Kawasan PUSPIPTEK Serpong, Tangerang Selatan, Indonesia 15343 \\ *E-mail: reza.ulum@ui.ac.id
}

Masuk tanggal : 06-01-2021, revisi tanggal : 26-01-2021, diterima untuk diterbitkan tanggal 30-04-2021

\begin{abstract}
Abstrak
Pemanfaatan terak sebagai sumber daya sekunder umumnya diolah dengan proses reduksi dengan reduktor batu bara atau dengan pelindian. Namun, pada penelitian kali ini digunakan reduktor cangkang kelapa sawit sebagai alternatif pengganti batu bara. Reduktor ini dipilih karena ketersediannya di Indonesia yang memadai. Tujuan dari penelitian ini adalah untuk mengetahui pengaruh reduktor cangkang kelapa sawit dan konsentrasinya terhadap proses reduksi terak feronikel yang telah dilakukan fusi alkali sebelumnya. Bahan awal merupakan terak feronikel yang telah dihaluskan kemudian dilakukan proses fusi alkali dengan ditambahkan 20 \% berat aditif natrium karbonat $\left(\mathrm{Na}_{2} \mathrm{CO}_{3}\right)$ kemudian dilakukan roasting. Sampel tersebut kemudian dicampurkan dengan reduktor cangkang kelapa sawit dengan perbandingan (reduktor : sampel) yaitu 15:85, 20:80, dan 25:75 dalam persen berat. Sampel yang telah dicampur kemudian dikompaksi. Proses reduksi dilakukan dengan menggunakan tube furnace pada temperatur $1100{ }^{\circ} \mathrm{C}$ selama 60 menit dengan laju pemanasan $10{ }^{\circ} \mathrm{C} /$ menit. Cangkang kelapa sawit dianalisis dengan menggunakan ultimate dan proximate analysis, sedangkan produk hasil reduksi kemudian dilakukan penghalusan dan pemisahan magnet secara manual. Produk hasil yang bersifat magnet dikarakterisasi dengan SEM-EDS (scanning electron microscope-energy dispersive spectrometry) dan XRD (x-ray diffraction). Pada penelitian ini didapatkan bahwa proses reduksi menggunakan reduktor cangkang kelapa sawit menghasilkan produk berupa natrium silikat, hematit, magnetit dan logam besi. Konsentrasi reduktor optimum dalam penelitian ini adalah 15 \%berat reduktor.
\end{abstract}

Kata Kunci: Terak feronikel, fusi alkali, proses karbotermik

\begin{abstract}
The utilization of slag as a secondary resource is usually processed by a reduction process with coal reducing agents or by a leaching process. However, this study will use palm kernel shell as an alternative reducing agent to substitute coal. Palm kernel shell was chosen as an alternative reducing agent because of their availability in Indonesia. The purpose of this study is to determine the effect of palm kernel shell as a reducing agent and its concentration (wt.\%) on the ferronickel slag reduction process. The raw material is the ground-ferronickel slag, which had been proceeded by alkali fusion by adding $20 \mathrm{wt} . \%$ sodium carbonate $\left(\mathrm{Na}_{2} \mathrm{CO}_{3}\right)$ as an additive and then roasted. The roasted product is then mixed with palm kernel shell reductant by the ratio (reductant : sample), which are 15:85, 20:80, and 25:75 in weight percent. Samples that have been mixed are then compacted. The reduction process is then carried out using a tube furnace at a temperature of $1100{ }^{\circ} \mathrm{C}$ for 60 minutes with a heating rate of $10{ }^{\circ} \mathrm{C} /$ minute. The palm kernel shells were analyzed using ultimate and proximate analysis, while the reduced product was characterized ground and manually separated magnetically. The magnetic samples were then characterized by SEM-EDS (scanning electron microscope-energy dispersive spectrometry) and XRD (x-ray diffraction). In this study, it was found that the reduction process using palm kernel shell produces products in the form of natrium silicate, hematite, magnetite, and iron metal. The optimum reducing agent concentration in this study is by adding $15 \mathrm{wt} . \%$ reductants.
\end{abstract}




\section{INTRODUCTION}

Nickel laterite is the result of natural weathering from ultramafic processes. Based on the chemical composition, nickel types laterite are divided into two, which are limonite and saprolite. Limonite $\left(\mathrm{FeO}(\mathrm{OH})-\mathrm{nH}_{2} \mathrm{O}\right)$ has a nickel composition of $0.7-1 \%$ from the total mass and has a rich iron $(\mathrm{Fe})$ composition. On the other hand, saprolite $\left.(\mathrm{Ni}, \mathrm{Mg}) \mathrm{Si}_{4} \mathrm{O}_{5}(\mathrm{OH})_{4}\right)$ contains 1.5$2.5 \%$ of nickel with a high amount of $\mathrm{Mg}-\mathrm{SiO}_{2}$ [1]. The products from nickel laterite by pyrometallurgical processing are both ferronickel and its by-product known as slag.

One of the methods to utilize ferronickel slag is to reduce the slag by using a reducing agent. In general, the reduction process uses coal or coke as the reducing agent. The ferronickel slag is considered as waste; thus, a low-cost reduction operation needs to be used. Palm kernel shells is an alternative reducing agent with a low selling value compared to coal or even coke. Similar to that of coal, the reduction reactions of palm kernel shell will involve the oxidation of carbon to $\mathrm{CO}$ gas, which acts as a reducing gas in the carbothermic reaction.

The palm kernel shell is considered a biomass product that has a high-calorie content and a high net calorific value. It provides a great number of burning calories and leads to significant heat generation from its combustion [2]. Its high calorific value means that the palm kernel shell has the potential to be also used as an alternative energy source to replace coal.

The palm kernel shell availability is relatively abundant because Indonesia is a tropical country with several palm oil land. Indonesia is the largest palm oil producer in the world [3]. As the palm oil industry and land in the industry developed, the production of waste from palm oil extraction will also increase every year. The palm kernel shell waste is usually disposed of immediately. The waste will give a negative impact on the surrounding environment if it is not managed carefully.

Arum Cahyanurani S. et al., [4] reported that the valuable metals in the slag are difficult to be separated due to their bonding in the silica-iron matrix in the fayalite phase, which is a dominant phase in ferronickel slag. Moreover, M. D. Alfariz et. al., [5] reported that increasing nickel and iron content can be obtained by the reduction process of ferronickel slag using palm kernel shell charcoal as reducing agent and $\mathrm{Na}_{2} \mathrm{CO}_{3}$ as an additive in one stage. The use of the additive in alkali fusion can facilitate the decomposition of the silica-iron matrix which leads to easier precious metals recovery. By combining the alkali fusion and reduction (carbothermic) process in different stages, this study aims to analyze the products of the alkali fusion and carbothermic reduction of ferronickel slag using palm kernel shell as a reducing agent.

\section{Materials AND MethodS}

The ground ferronickel slag with particle size 75 microns was used in this study. The sample was first treated by alkali fusion processing. This process was carried out by mixing the sample with 20 wt.\% sodium carbonate, compacting the sample and heating the sample in the tube furnace for 1 hour at $1100{ }^{\circ} \mathrm{C}$. At the end of each experiment, the product was furnace cooled. Before the carbothermic process was conducted, the sample was then ground and mixed by 15,20 , and 25 wt. $\%$ palm kernel shell as a reductant, and the mixtures were compacted. Proximate and ultimate analysis was carried out to determine the main content of the reducing agent used in the experiments. The proximate and ultimate test results can be seen in Table 1 and Table 2. Meanwhile, the initial slag composition from the XRF (x-ray flourescence) analysis is shown in Table 3.

The carbothermic process was performed by heating the sample in the tube furnace at $1100{ }^{\circ} \mathrm{C}$ for 1 hour in an inert atmosphere, with a heating rate of $10^{\circ} \mathrm{C} /$ minute. The carbothermic product was then ground and separated magnetically by a permanent magnet manually. The magnetic particles from each carbothermic product are then characterized by SEM-EDS (scanning electron mycroscope-energy dispersive spectroscopy) and XRD (x-ray diffraction) for further analysis.

Table 1. Proximate analysis results

\begin{tabular}{llc} 
No. & \multicolumn{2}{c}{ Palm Kernel Shell } \\
& \multicolumn{2}{c}{ Proximate analysis results (\%) } \\
\hline 1 & Moisture & 6.10 \\
2 & Ash & 3.36 \\
3 & Volatile Matter & 12.00 \\
4 & Fixed Carbon & 78.54 \\
\hline
\end{tabular}

Table 2. Ultimate analysis results

\begin{tabular}{llc}
\hline No. & \multicolumn{2}{c}{ Palm Kernel Shell } \\
& \multicolumn{2}{c}{ Ultimate analysis result $(\%)$} \\
\hline 1 & Sulphur & 0.02 \\
2 & Carbon & 80.79 \\
3 & Hydrogen & 2.85 \\
4 & Nitrogen & 0.89 \\
5 & Oxygen & 12.09 \\
\hline
\end{tabular}


Tables 1 and 2 show that the carbon content of palm kernel shells is $80.79 \%$ and it has a fixed carbon level of $78.54 \%$. The higher the carbon content in a reducing agent, the more likely $\mathrm{CO}$ $\mathrm{CO}_{2}$ will be formed and act as the main reducing agent for the reduction process [6]. The slag's major components are $\mathrm{SiO}_{2}, \mathrm{Fe}_{2} \mathrm{O}_{3}, \mathrm{MgO}, \mathrm{Al}_{2} \mathrm{O}_{3}$, and others as shown in Table 3.

Table 3. Slag initial composition from XRF analysis

\begin{tabular}{llllll}
\hline Compounds & $\mathrm{Na}_{2} \mathrm{O}$ & $\mathrm{MgO}$ & $\mathrm{Al}_{2} \mathrm{O}_{3}$ & $\mathrm{SiO}_{2}$ & $\mathrm{CaO}$ \\
\hline Wt.\% & 0.56 & 29.5 & 5.34 & 46.76 & 0.81 \\
\hline Compounds & $\mathrm{Fe}_{2} \mathrm{O}_{3}$ & $\mathrm{NiO}$ & $\mathrm{ZnO}$ & $\mathrm{Cr}_{2} \mathrm{O}_{3}$ & Others \\
\hline Wt.\% & 13.3 & 0.085 & 0.029 & 1.55 & 2.066 \\
\hline
\end{tabular}

\section{RESULTS AND DisCUSSIONS}

The XRD (x-ray diffraction) result of the alkali fusion product is shown in Fig. 1. The compounds contained in the product from alkali fusion, which is named as a roasted product in this study, are quartz $\left(\mathrm{SiO}_{2}\right)$, sodium silicate $\left(\mathrm{Na}_{2} \mathrm{SiO}_{3}\right)$, fayalite $\left(\mathrm{Fe}_{2} \mathrm{SiO}_{4}\right)$, and hematite $\left(\mathrm{Fe}_{2} \mathrm{O}_{3}\right)$. The sodium silicate $\left(\mathrm{Na}_{2} \mathrm{SiO}_{3}\right)$ appears to form during the alkali fusion process; this was not identified in the previous study [4]-[5].

\subsection{Alkali Fusion Results}

Sodium silicate is formed by the reaction between $\left(\mathrm{Na}_{2} \mathrm{CO}_{3}\right)$ and quartz according to reactions (1) to (3) [7].

$$
\begin{aligned}
& \mathrm{Na}_{2} \mathrm{CO}_{3} \rightarrow \mathrm{Na}_{2} \mathrm{O}+\mathrm{CO}_{2} \\
& \mathrm{Na}_{2} \mathrm{O}+\mathrm{SiO}_{2} \rightarrow \mathrm{Na}_{2} \mathrm{SiO}_{3} \\
& \mathrm{Na}_{2} \mathrm{CO}_{3}+\mathrm{SiO}_{2} \rightarrow \mathrm{Na}_{2} \mathrm{SiO}_{3}+\mathrm{CO}_{2}
\end{aligned}
$$

Reactions (1) to (3) in this study occurs between sodium carbonate and silicate from the ferronickel slag which produces $\mathrm{Na}_{2} \mathrm{SiO}_{3}$. First, the additive sodium carbonate $\left(\mathrm{Na}_{2} \mathrm{CO}_{3}\right)$ decomposes into sodium oxide $\left(\mathrm{Na}_{2} \mathrm{O}\right)$ and carbon dioxide $\left(\mathrm{CO}_{2}\right)$ via reaction (1). The sodium oxide $\left(\mathrm{Na}_{2} \mathrm{O}\right)$ is then reacted with quartz $\left(\mathrm{SiO}_{2}\right)$ to produce sodium silicate $\left(\mathrm{Na}_{2} \mathrm{SiO}_{3}\right)$ according to reaction (2) [7]. The sodium carbonate additive $\left(\mathrm{Na}_{2} \mathrm{CO}_{3}\right)$ can react with the fayalite phase $\left(\mathrm{Fe}_{2} \mathrm{SiO}_{4}\right)$ which produces several compounds such as hematite $\left(\mathrm{Fe}_{2} \mathrm{O}_{3}\right)$, sodium silicate $\left(\mathrm{Na}_{2} \mathrm{SiO}_{3}\right)$, and carbon monoxide gas (CO) based on the reaction of (4) [8]. The products formed in this study are similar to those reported in the literature from the roasting process using sodium carbonate $\left(\mathrm{Na}_{2} \mathrm{CO}_{3}\right)$ at a temperature of $1100{ }^{\circ} \mathrm{C}[7]$.

$\mathrm{Fe}_{2} \mathrm{SiO}_{4}+\mathrm{Na}_{2} \mathrm{CO}_{3} \rightarrow \mathrm{Fe}_{2} \mathrm{O}_{3}+\mathrm{Na}_{2} \mathrm{SiO}_{3}+\mathrm{CO}$
SEM-EDS (scanning electron microscopeenergy dispersive spectroscopy) analysis for the roasted products (before the carbothermic process is conducted) is shown in Fig. 3. Figure 3 shows that 4 different locations in the sample have been analyzed to determine the elemental content of the roasted product, which is shown in Table 4 . Figure 3 shows that the morphology of the roasted product consists of dominant colors of black and gray (dark) which indicated the domination of oxygen/oxide compound.

The observation areas of numbers 1 and 4 have a similarity based on their white color's appearance. According to Table 1, it can be analyzed that the Fe levels in the observation areas of numbers 1 and 4 are the highest compared to other observation areas. The white areas have high iron content, i.e. 10.7 and 14.8 wt.\% for areas number 1 and 4 with, respectively. In the area of number 2, a dominant gray (dark) color can be observed. This indicates the predominant constituent of oxygen at $41.3 \mathrm{wt} . \%$. While in area number 3, a slightly mixed gray (dark) and white content can be observed. Area number 3 consists of 39.2 wt.\% oxygen.

\subsection{Carbothermic Process Results}

After the carbothermic process is done, all of the samples were ground into a powder, separated magnetically using a permanent magnet. Almost all of the particles were attracted to the magnet. This carbothermic product was then characterized by XRD and SEM-EDS analysis. The effect of palm kernel shell utilization as a reductant on the carbothermic process of the roasted product from the XRD analysis is shown in Fig. 3. The combination of alkali fusion and carbothermic process shows a tendency to decompose the fayalite phase producing some compounds that can be reduced easier during the carbothermic reduction process. This results in the formation of hematite, magnetite, and iron metal.

Hematite formed due to the fayalite reaction with the additives will be reduced to magnetite, to wustite $(\mathrm{FeO})$, and eventually to ferrous metal $(\mathrm{Fe})$ according to the reaction (5) to (7)[9].

$3 \mathrm{Fe}_{2} \mathrm{O}_{3}+\mathrm{CO} \rightarrow 2 \mathrm{Fe}_{3} \mathrm{O}_{4}+\mathrm{CO}_{2}$

$\mathrm{Fe}_{3} \mathrm{O}_{4}+\mathrm{CO} \rightarrow 3 \mathrm{FeO}+\mathrm{CO}_{2}$

$\mathrm{FeO}+\mathrm{CO} \rightarrow \mathrm{Fe}+\mathrm{CO}_{2}$

Besides, it clearly shows the inequality between one and two stages of the alkali fusion and reduction (carbothermic) process. $\mathrm{Fe}$ phase formed when two stages of heat treatment were performed, while $\mathrm{Fe}$ was bonded in the phase of 
fayalite when heat treatment carried out in one stage [5].

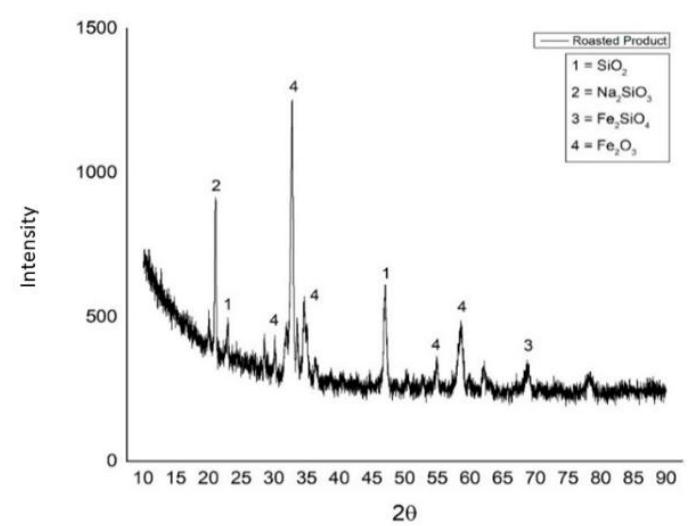

Figure 1. XRD analysis result of the roasted product

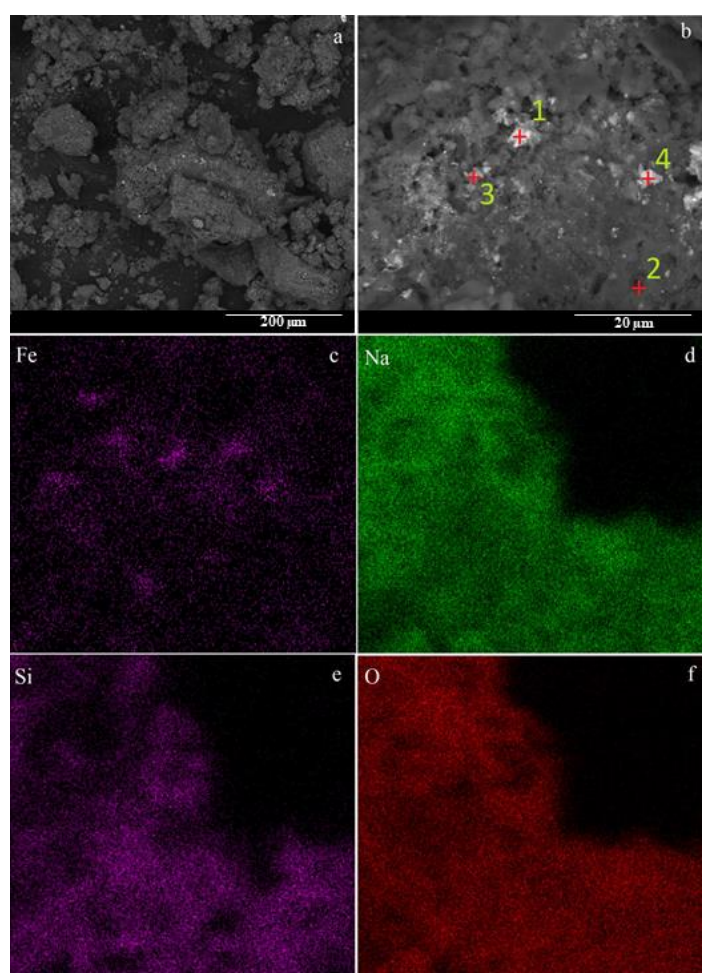

Figure 2. SEM-EDS analysis showing elemental mapping analysis of the roasted product

The effect of variation of palm kernel concentration on the formations of iron $(\mathrm{Fe})$, hematite $\left(\mathrm{Fe}_{2} \mathrm{O}_{3}\right)$, and magnetite $\left(\mathrm{Fe}_{3} \mathrm{O}_{4}\right)$ detected in the carbothermic products can be analyzed by XRD analysis. Based on the analysis of the peak height of the iron metal phase, the palm kernel shell addition of $15 \mathrm{wt} \%$ appears to give the highest $\mathrm{Fe}$ peak, followed by the palm kernel shell addition of $25 \mathrm{wt} . \%$ and $20 \mathrm{wt} . \%$.

The hematite compound's peak height appears to be at the highest at 25 wt.\% palm kernel shell addition, followed by the 15 wt. $\%$ and 20 wt.\% palm kernel shell. Meanwhile, the magnetite compound's peak height appears to be at the highest at 15 wt.\% palm kernel shell addition, followed by $25 \mathrm{wt} . \%$ and $20 \mathrm{wt} . \%$ palm kernel shell addition.

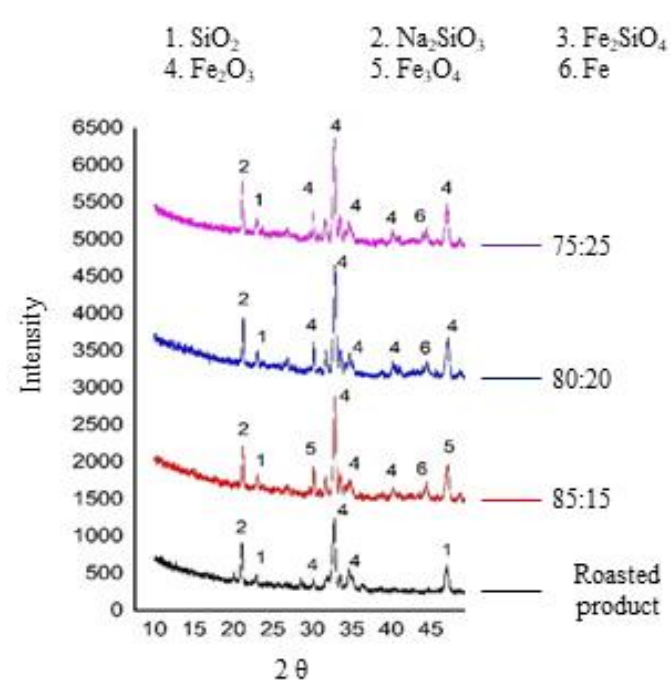

Figure 3. XRD analysis results of the carbothermic products from 75:25, 80:20 and 85:15 (roasted product : palm kernel shell reductant: 25, 20 and 15 wt.\% respectively)

Based on the three prominent peaks in this study, the carbothermic process seems to give the most to the less optimum result at the palm kernel shell addition of $15 \mathrm{wt} . \%, 25 \mathrm{wt} . \%$, and $20 \mathrm{wt} . \%$. To further validate the result, the elemental mapping by SEM-EDS analysis is performed on the carbothermic product from the $15 \mathrm{wt} . \%$ palm kernel shell addition as shown in Fig. 4.

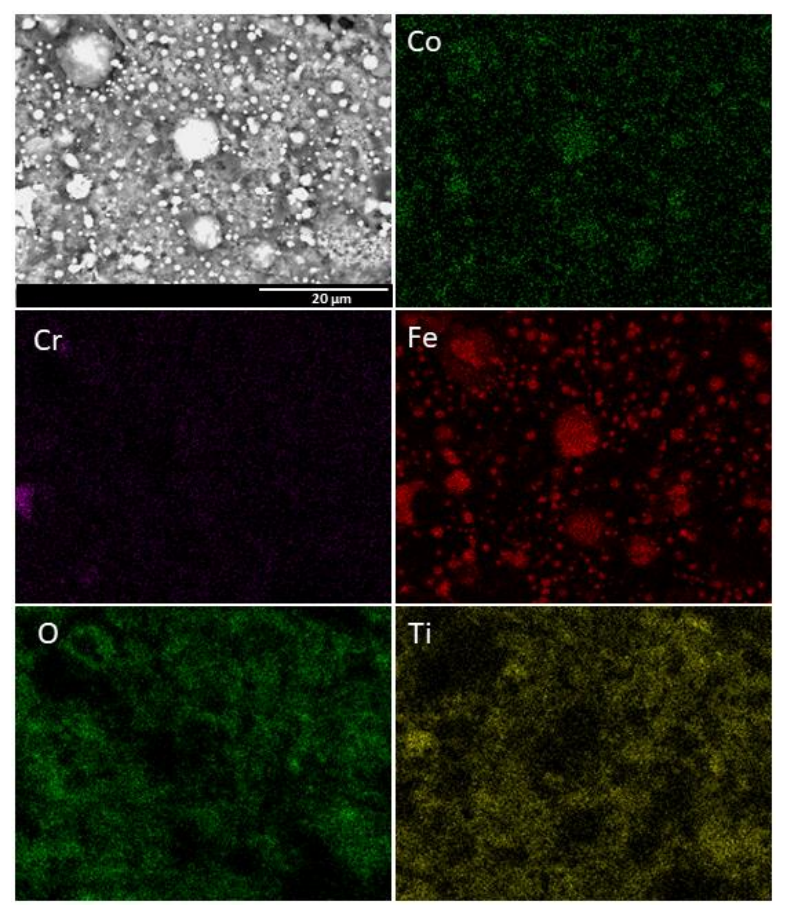

Figure 4. SEM-EDS analysis showing elemental mapping analysis of the carbothermic reduction product from $15 \mathrm{wt} . \%$ palm kernel shell addition 
Tabel 4. SEM-EDS analysis of the initial roasted product shown in the Fig. 2

\begin{tabular}{ccccc}
\hline \multirow{2}{*}{$\begin{array}{c}\text { Element } \\
(\mathbf{w t} / \%)\end{array}$} & $\mathbf{1}$ & $\mathbf{2}$ & $\mathbf{3}$ & $\mathbf{4}$ \\
\cline { 2 - 5 } $\mathrm{O}$ & 30.4 & 41.3 & 39.2 & 26.1 \\
$\mathrm{Na}$ & 35.2 & 27.4 & 31.2 & 21.7 \\
$\mathrm{Mg}$ & 0.68 & 0.19 & 0.13 & 0.51 \\
$\mathrm{Al}$ & 5.19 & 10.7 & 7.30 & 4.63 \\
$\mathrm{Si}$ & 7.8 & 11.4 & 8.92 & 6.03 \\
$\mathrm{P}$ & 3.04 & 2.20 & 5.44 & 2.74 \\
$\mathrm{Sn}$ & 0.87 & 0.56 & 0.6 & 4.56 \\
$\mathrm{Ca}$ & 1.42 & 2.76 & 1.81 & 4.58 \\
$\mathrm{Ti}$ & 0.65 & 0.45 & 1.16 & 3.92 \\
$\mathrm{Mn}$ & 0.81 & 0.29 & 0.34 & 4.37 \\
$\mathrm{Fe}$ & 10.7 & 1.96 & 2.95 & 14.8 \\
$\mathrm{Co}$ & 1.35 & 0.44 & 0.44 & 3.21 \\
$\mathrm{Ni}$ & 1.35 & 0.35 & 0.51 & 2.85 \\
\hline
\end{tabular}

As shown in Fig. 4, it indicates that the carbothermic product from the 15 wt.\% palm kernel shell addition consists of Fe-containing particles formed after the alkali fusion and carbothermic process. The SEM-EDS result shown in Fig. 4 is in agreement with the XRD result provided in Fig. 3.

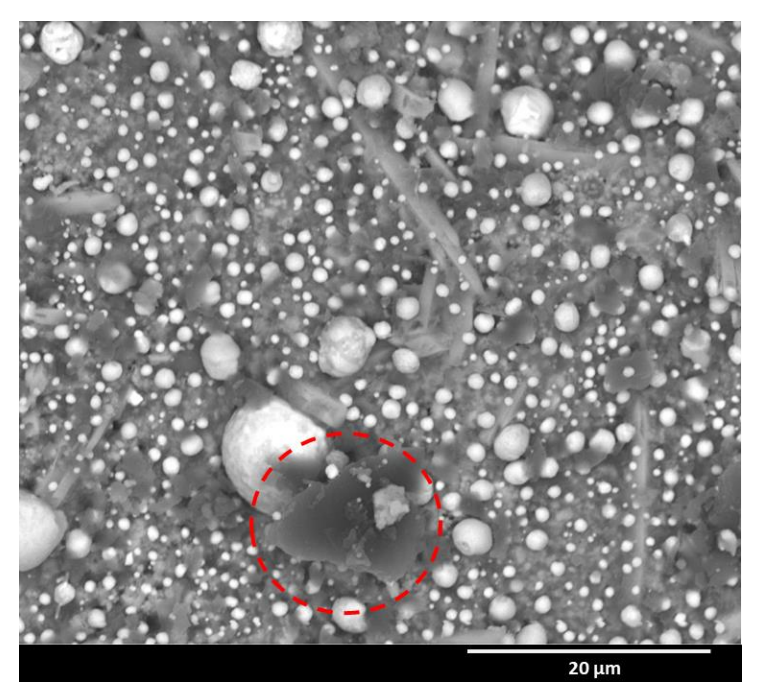

Figure 5. SEM-EDS analysis of the carbothermic reduction product from $20 \mathrm{wt} . \%$ palm kernel shell addition

It is expected that the more palm kernel shell addition, the more metallic iron would be produced since there is more carbon source. However, the present result shows contradiction. The contradiction can be explained by SEM-EDS analysis of the carbothermic products from the 20 wt.\% palm kernel shell addition is shown in Fig. 5. Figure 5 indicates that the more palm kernel shell addition, the more dark particles are observed in the carbothermic product (area marked with a dashed circle in Fig.5). According to EDS analysis shown in Table 5, the particles are dominantly composed of carbon. The result indicates that the carbon source was not completely oxidized into $\mathrm{CO}$ or $\mathrm{CO}_{2}$ gas which may be caused by the lack of carbothermic reduction time. The residual carbon may be avoided by the use of the finer size of palm kernel shell to accelerate the formation of $\mathrm{CO} / \mathrm{CO}_{2}$ gas during the carbothermic reduction process.

Tabel 5. SEM-EDS analysis of the carbothermic reduction product shown the Fig. 5

\begin{tabular}{lcl}
\hline Element & Wt.\% & At.\% \\
\hline $\mathrm{C}$ & 73.31 & 82.55 \\
$\mathrm{O}$ & 14.63 & 12.37 \\
$\mathrm{Na}$ & 3.86 & 2.27 \\
$\mathrm{Mg}$ & 0.51 & 0.28 \\
$\mathrm{Al}$ & 0.82 & 0.41 \\
$\mathrm{Si}$ & 1.33 & 0.64 \\
$\mathrm{P}$ & 0.67 & 0.29 \\
$\mathrm{Sn}$ & 0.81 & 0.09 \\
$\mathrm{Ca}$ & 1.04 & 0.35 \\
$\mathrm{Ti}$ & 0.44 & 0.12 \\
$\mathrm{Cr}$ & 0.16 & 0.04 \\
$\mathrm{Mn}$ & 0.26 & 0.06 \\
$\mathrm{Fe}$ & 1.34 & 0.33 \\
$\mathrm{Co}$ & 0.51 & 0.12 \\
$\mathrm{Ni}$ & 0.31 & 0.07 \\
\hline
\end{tabular}

The present study demonstrates the possible application of the combined alkali fusion and carbothermic process for the treatment of ferronickel slag processing as a secondary source of iron. However, the energy consumption of the combined alkali fusion and the carbothermic process is relatively high due to the two separate heating stages applied in the process.

\section{Conclusions}

The use of alkali fusion followed by the carbothermic process results in the decomposition of the ferronickel slag. The silicairon matrix in the fayalite phase appears to change into different compounds, one of which is $\mathrm{Na}_{2} \mathrm{SiO}_{3}$. The carbothermic reduction products can be separated by a magnetic separation process. The optimal addition of palm kernel shell was at 15 wt.\% which produced various carbothermic products, such as natrium silicate, hematite, magnetite, and iron metal. 


\section{ACKNOWLEDGEMENT}

The authors would like to express their gratitude for the funding from PUTI 2020 Universitas Indonesia NKB-2028/UN2.RST/HKP.05.00/2020.

\section{REFERENCES}

[1] Tim-Bestekin, "Nickel Ore Sulawesi," 2016. [Online]. Available: https://bestekin.com/2016/02/01/nickelore-sulawesi/. [Accessed: 22-Sep-2019].

[2] R. Z. Abd Rashid, H. Mohd. Salleh, M. H. Ani, N. A. Yunus, T. Akiyama, and H. Purwanto, "Reduction of low grade iron ore pellet using palm kernel shell," Renewable Energy, vol. 63, pp. 617-623, 2014.

[3] R. Kurniawan and S. Managi, "Coal consumption, urbanization, and trade openness linkage in Indonesia," Energy Policy, vol. 121, pp. 576-583, 2018.

[4] A. C. Setyabrata, A. Maksum, A. B. Prasetyo, B. Priyono, and J. Wahyuadi Soedarsono, "Effect of Sodium Carbonate on the Reduction Process of Nickel Slag from Sulawesi," in IOP Conference Series: Materials Science and Engineering, vol. 553, no. 1, p. 012028 , 2019.

[5] M. D. Alfariz, W. Mayangsari, a. B. Prasetyo, A. Mksum, T. Prasetyo, R. M. Ulum, and J. W. Soedarsono, "Effect of sodium carbonate $\left(\mathrm{Na}_{2} \mathrm{CO}_{3}\right)$ additives and palm kernel shell charcoal to increase nickel and iron content from ferronickel slag using the pyrometallurgical method," in The 4th International Tropical Renewable Energy Conference (i-TREC 2019) AIP Conf. Proc., vol. 040030, pp. $1-6,2020$.

[6] J. W. Soedarsono, C. E. Arifin, J. S. Saragi, A. A. Putra, A. Kawigraha, R. D. S. Ariobimo, and A. Rustandi, "The effect of reduction parameter in processing lump ore with green sugarcane bagasse reductor in muffle furnace," in Materials Science Forum, vol. 893, pp. 195-201, 2017. Doi : 10.4028/www.scientific.net/MSF.893.195.

[7] A. B. Prasetyo, A. Maksum, J. W. Soedarsono1, and F. Firdiyono, "Thermal characteristics of ferronickel slag on roasting process with addition of sodium carbonate $\left(\mathrm{Na}_{2} \mathrm{CO}_{3}\right)$," in International Seminar on Metallurgy and Materials, vol. 541, pp. 012037, 2019. Doi: 10.1088/1757-899X/541/1/012037.

[8] M. Jiang, T. Sun, Z. Liu, J. Kou, N. Liu, and S. Zhang, "Mechanism of sodium sulfate in promoting selective reduction of nickel laterite ore during reduction roasting process," International Journal of Mineral Processing, vol. 123, pp. 3238, 2013.

[9] S. K. Haldar, Mineral Exploration Principles and Applications, 2nd ed. Elsevier, 2018. 